Review Paper

\title{
A concise review on performance improvement of solar stills
}

\author{
S. Shankara Narayanan ${ }^{1}$ (D $\cdot$ Apurv Yadav $^{2} \cdot$ Mohammad Nadeem Khaled $^{2}$
}

Received: 31 October 2019 / Accepted: 18 February 2020 / Published online: 28 February 2020

(c) Springer Nature Switzerland AG 2020

\begin{abstract}
Conversion of saline water into freshwater by the use of solar thermal energy is known as solar desalination and the devices used for carrying out solar desalination are known as solar stills. The major problem faced by the solar stills is that they have low productivity and therefore unable to meet the high demand for freshwater. Over the years, several researchers have worked on improving the productivity of solar stills. Preheating of feed water, forced convection and energy storage are some of the methods used to increase their efficiencies. Some of these methods are discussed in the present review. The main aim of the current review is to provide the researchers with an idea to select the appropriate method for the improvement in the performance of currently available solar stills.
\end{abstract}

Keywords Solar stills · Design modifications in solar stills · Performance of solar stills

\section{Introduction}

Almost $75 \%$ of the earth's surface is covered by water. Only $0.014 \%$ of this water is fit for human consumption. Most of the water present is in the form of brackish sea water which cannot be used directly [1]. The scarcity of clean freshwater is at a critical stage today in several countries. This type of crisis adversely affects agricultural and industrial sectors which are essential for human survival and development. Therefore, there is an extensive need for utilization and development of water distillation systems. Electrodialysis and reverse osmosis are two common techniques used for water distillation. In electrodialysis, a number of cells are connected in parallel between two electrodes. These cells have various cation and anion exchange membranes that form dilute solution and concentrated solution compartments. When an electric field is applied, the salt ions are transported from one solution to another through these membranes [2]. The schematic of one cell pair electrodialysis is shown in Fig. 1.
Reverse osmosis process has a semi-permeable membrane that provides a tortuous pathway to the water flow onto the permeate side. To overcome the osmotic pressure, another pressure has to be applied. These membranes can reject monovalent ions, molecules and other contaminants [3]. The schematic of reverse osmosis is shown in Fig. 2. However, these methods are expensive, complex and require skilled manpower for their operation and maintenance. Also, they are not portable which restricts their usage in remote areas. Solar distillation is a cheap and promising methodology for desalination applications. Solar radiation transmits through the glass cover of the still and is absorbed by the dark-colored insulator basin. This heat energy is then transferred to the water. Water also receives thermal energy through convection and radiation and evaporates. The water vapors condense on the inner surface of the sloped glass cover and trickle down towards the distillate container, while the impurities remain at the bottom of the basin [4]. The schematic of a conventional solar distillation unit is shown in Fig. 3.

S. Shankara Narayanan, shankar334@gmail.com | ${ }^{1}$ Material Research Laboratory, Department of Physics, School of Basic Sciences and Research, Sharda University, Greater Noida, Uttar Pradesh 201310, India. ${ }^{2}$ Department of Engineering, Amity University, Dubai 345019, United Arab Emirates. 


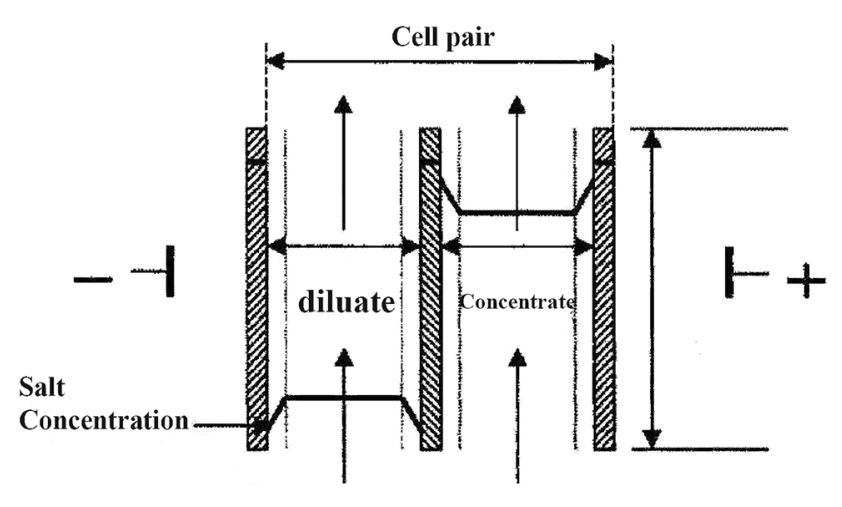

Fig. 1 Schematic diagram of one cell pair electrodialysis [2]

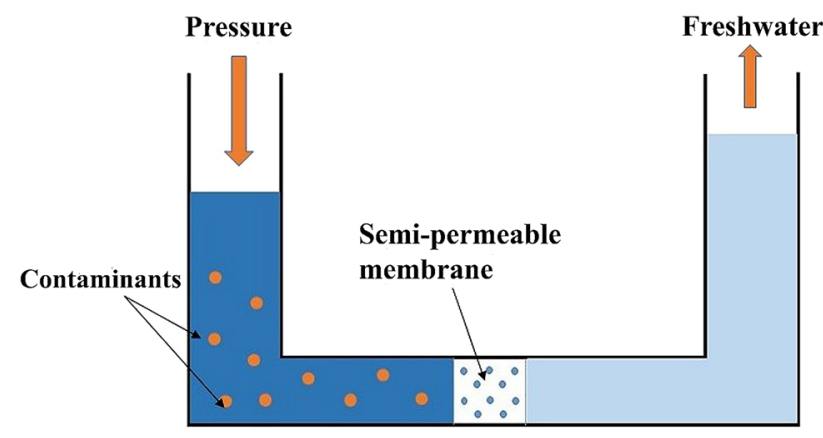

Fig. 2 Schematic diagram of reverse osmosis process

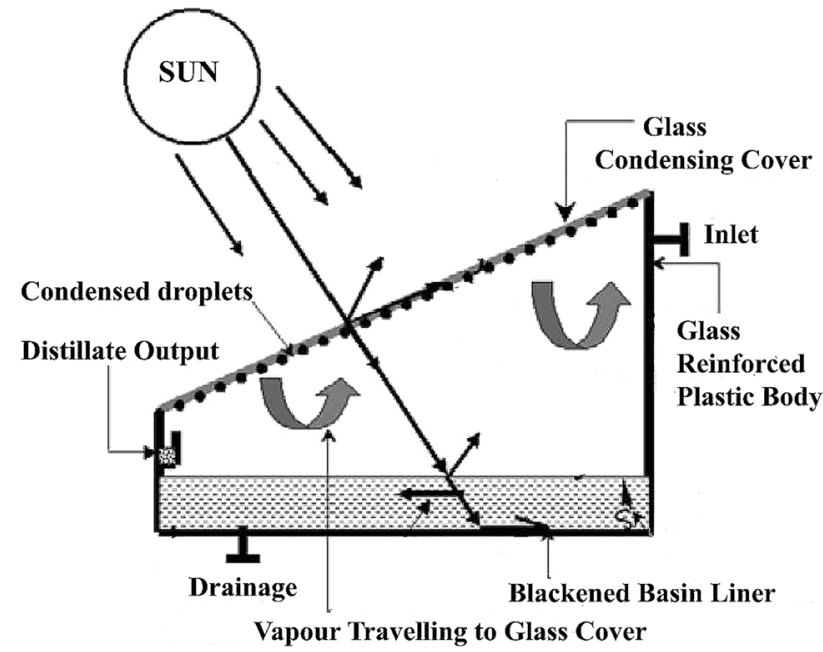

Fig. 3 Conventional solar distillation unit [4]

There are several extensive studies on the testing of solar still for water desalination. These studies took into consideration the effect of factors such as ambient temperature, solar radiation intensity, wind velocity, water depth, glass cover temperature and other parameters.
The reported efficiency of single slope solar water distillation was in the range of $35-45 \%$ and productivity was less than $5 \mathrm{~L} / \mathrm{m}^{2}$ per day. Many types of design modifications have been applied by the researchers to overcome the low efficiency [5].

Modification of solar stills to make it compatible with small scale applications makes it imperative to have a clear understanding of the factors which affect the performance and productivity of a solar still. Intensity of sunlight [6], depth of basin water [7], thickness of glass cover [8], slope of glass cover [9], wind velocity [10], temperature difference between water and glass plate [11], free surface area of water [12] selective surface coatings [13] and insulation [14] are some of the factors which influence the working of a solar still. Meteorological parameters such as sunlight intensity and wind velocity cannot be controlled, but regulation of other controllable parameters has been used to study the effect on the productivity of solar stills. The present review aims to provide concise data for the researchers, involved in the design of a solar still, to gain quick insight into how different parameters affect the performance of solar stills.

\section{Classification of solar stills}

Active and passive solar stills are two major classification of solar stills. The stills in which sunlight is used directly to evaporate the water comes under the category of passive solar stills. They do not rely on any external devices and operate on the Zeroth law of thermodynamics. In the active solar stills, some additional setup is used to enhance the heat transfer to accelerate evaporation. It can be done through some design modification, integration of an additional device or the combination of both. The solar stills can be further sub-classified into the following three categories.

\subsection{Basin still}

It is the most simple or conventional type of solar still. It is depicted in Fig. 3 and its mechanism has already been discussed above.

\subsection{Wick still}

The design of a wick type solar still is presented in Fig. 4. The wick is a porous material or cloth which is kept at the bottom of the container. The sunlight falling on it transmits through the glass and absorbed by the wick's surface. Due to capillary action, the water flowing through the wick rises to its surface and gets heated by the absorbed thermal energy. The heated water evaporates and gets 


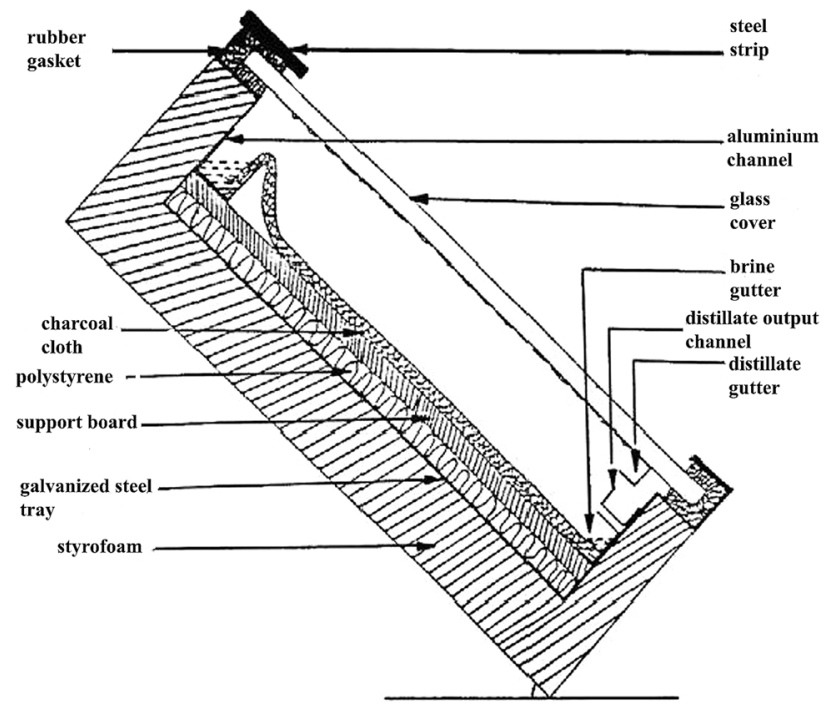

Fig. 4 Wick-type solar still [15]

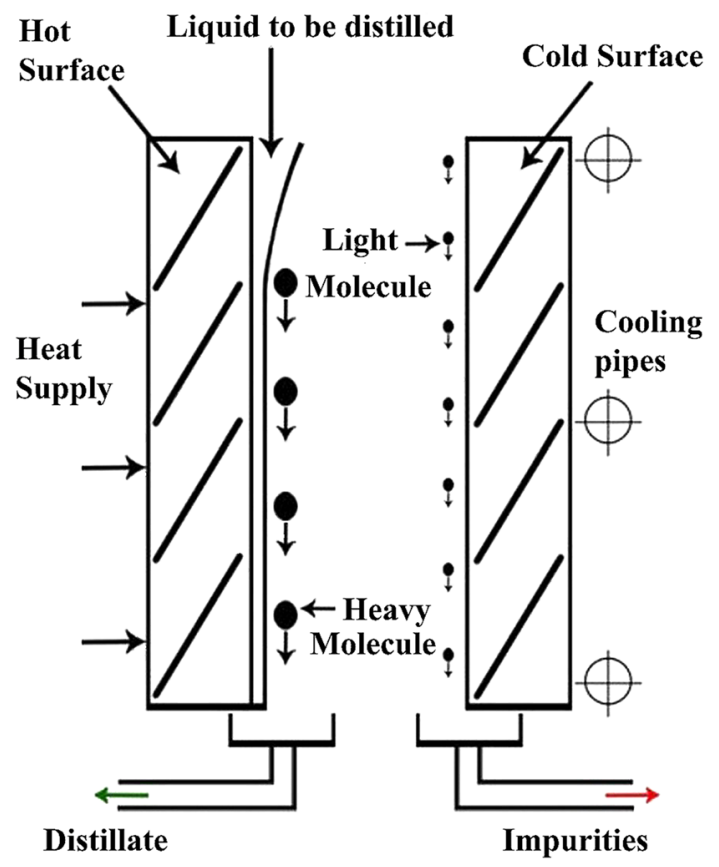

Fig. 5 Schematic diagram of diffusion still

condensed on the inner side of the glass plate by losing its latent heat of evaporation. These condensed droplets trickle down on the sloped glass surface and get collected in a container through the drainage provided for it.

\subsection{Diffusion still}

In this type of still, two surfaces which are maintained at hot and cold temperatures are held parallel to each other. The schematic of diffusion still is presented in Fig. 5. The gap thickness between these surfaces is kept very small to suppress convective heat transfer. The hot surface acts as a membrane between the cold side and the glass cover. Thermal energy from the sun is absorbed by the front side of this membrane. As water flows through the membrane, it evaporates and diffuses through the gap and gets condensed on the cold side. This water then gets collected into a container due to gravity. There have been many design modifications in the solar still since its conception. These modifications incorporated regulation of parameters affecting the solar still performance, the coupling of two or more distillation processes or the addition of a separate mechanism to enhance the productivity of the stills.

\section{Parameters affecting the productivity of solar stills}

\subsection{Climatic conditions}

The increase in the intensity of solar radiation improves the efficiency and productivity of the solar still. Particularly, solar stills achieve their highest efficiency during the afternoon as during that time maximum solar radiation intensity reaches the earth which increases the temperature of the water and facilitates a faster evaporation rate. The speed of wind flowing over the glass plate also has a significant effect on the performance of solar still. As the wind speed increases, convective heat transfer from the top of the glass surface reduces its temperature. Due to this, more distillate condenses on the inner surface of the glass plate, increasing the productivity of the still.

\subsection{Basin water depth}

Several researchers have focused on the effect of water depth in increasing the productivity of a solar still. It is found to be an important factor and the rate of evaporation in a still is found to be inversely proportional to basin water depth [16]. Tiwari, Sumegha and Yadav [17] investigated the effect of seven different depths of basin water $(0.02 \mathrm{~m}, 0.04 \mathrm{~m}, 0.06 \mathrm{~m}, 0.08 \mathrm{~m}, 0.10 \mathrm{~m}, 0.12 \mathrm{~m}$ and $0.14 \mathrm{~m}$ ) as shown in Fig. 6 . The daily distillate output was found to be above $3 \mathrm{~kg} / \mathrm{m}^{2}$ at $0.02 \mathrm{~m}$ of water depth while it reduced continuously on increasing the depth and at a depth of $0.14 \mathrm{~m}$, output decreased to only around $1.2 \mathrm{~kg} / \mathrm{m}^{2}$. Elango and Murugavel [18] conducted experiments on the single and double basin, double slope solar stills with varying basin depth. In both cases, the productivity of the units was found to decrease with increasing water depth. Rajamanickam and Ragupathy [19] investigated the influence of water depth on solar stills and obtained similar results. Khalifa 
Fig. 6 Variation in a distillate output and $\mathbf{b}$ efficiency with basin water depth [17]

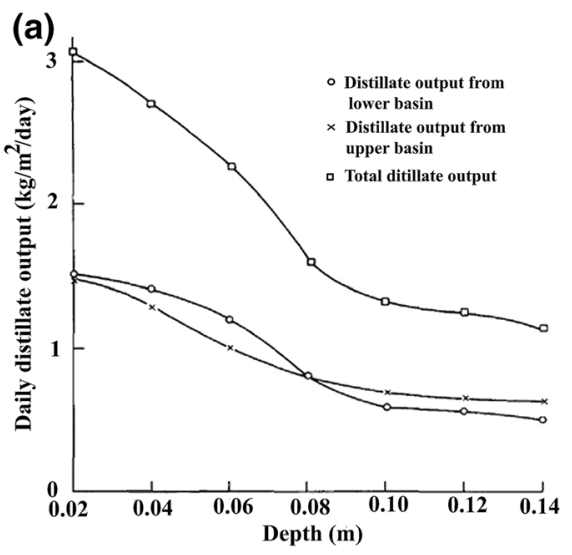

(b)

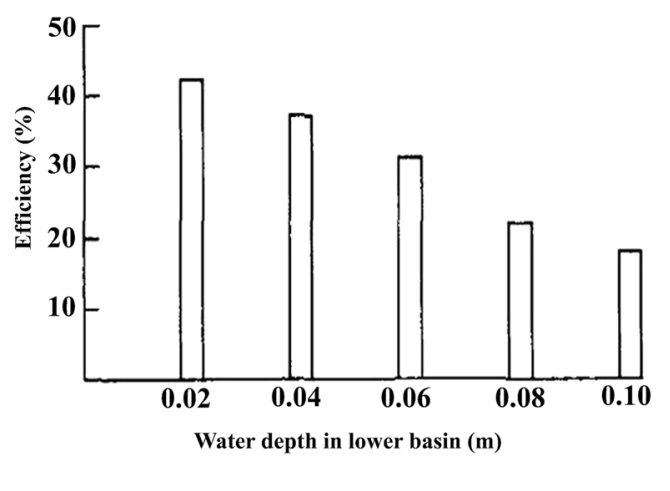

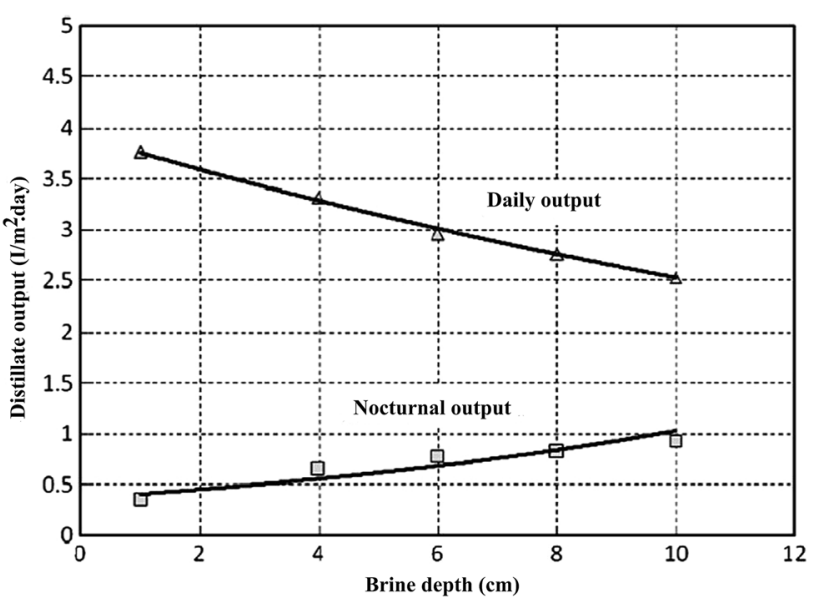

Fig. 7 Daily and nocturnal productivity with basin water depth [20]

and Mahmood [20] tested the productivity of a solar still by varying the basin water depth by 1, 4, 6, 8 and $10 \mathrm{~cm}$. The productivity was found to decrease by increasing the water depth as shown in Fig. 7. However, nocturnal productivity was found to increase with the increase in water depth. Experiments were also conducted by researchers on solar stills with deep basins [21]. As the depth of basin water is increased, there was a continuous decrease in the daily productivity of the still, while the overnight productivity followed a reverse trend. The results of the experiment are depicted in Fig. 8. In a solar still, as the depth of the basin water increases the volume and volumetric heat capacity of water increases. Due to the increase in volumetric heat capacity, the temperature of water reduces for the same solar intensity. This consequently leads to a low evaporation rate. During the night, the heat energy absorbed by the water is released and desalination continues to take place. As more volume of water absorbs more energy, the evaporation for the shallow basin is less compared to a deep basin at night [22]. The basin water depth in the range of $2-6 \mathrm{~cm}$ has been recommended in most of the studies

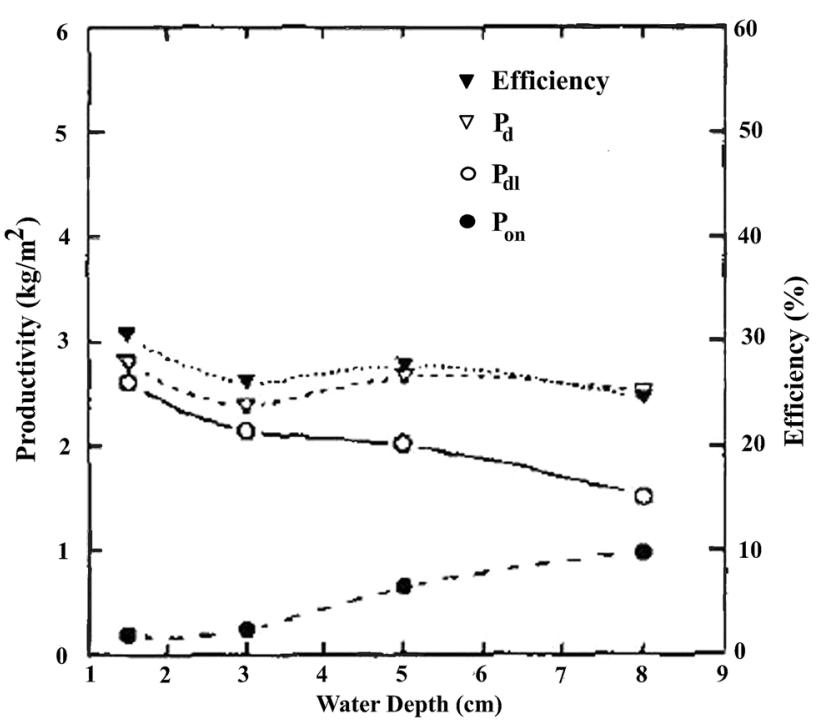

Fig. 8 Effect of change in basin water depth on efficiency and daily, daylight and overnight productivity [21]

[23]. The effect of basin water depth on the productivity of solar stills in some of the studies has been presented in Table 1.

\subsection{Slope of the cover}

It is observed that the slope of the cover of solar still directly affects its productivity [24]. A suitable inclination maximizes the absorption of sunlight and increases the flow of condensed droplets into the condensate container. The angle of slope should be such that it minimizes the reflection of sunlight from the cover and also that a sufficient amount of condensed droplets trickles down to the collector instead of falling in the basin water [25]. As the change in slope brings about a number of changes in the still, its effect on the productivity of the still is the resultant of, but not limited to, following parameters: 
Table 1 Summary of works on solar still related to brine depth

\begin{tabular}{|c|c|c|c|c|c|c|c|}
\hline S. no. & Type of still & Location latitude & Tilt angle & Season/month & Brine depth range $(\mathrm{cm})$ & $\begin{array}{l}\text { Productivity } \\
\text { enhancement (\%) }\end{array}$ & References \\
\hline 1 & Double slope & $11^{\prime} 39^{\circ} \mathrm{N}$ & $11^{\circ}$ & Winter & $1,2.5,5$ and 7.5 & 11 & [19] \\
\hline 2 & Single slope & $28^{\prime} 37^{\circ} \mathrm{N}$ & $10^{\circ}$ & November & $2,4,6$ and 8 & 34 & [92] \\
\hline 3 & Single slope & $28^{\prime} 37^{\circ} \mathrm{N}$ & $28^{\prime} 37^{\circ}$ & Winter & 5,10 and 15 & 8 & [93] \\
\hline 4 & Double slope & $30^{\prime} 58^{\circ} \mathrm{N}$ & $5^{\circ}$ & - & $0.5,2,3$ and 4 & 23 & [94] \\
\hline 5 & Plastic & $18^{\prime} 15^{\circ} \mathrm{N}$ & $20^{\circ}$ & Winter & $2,4,6,8,10$ and 12 & 34 & [95] \\
\hline
\end{tabular}

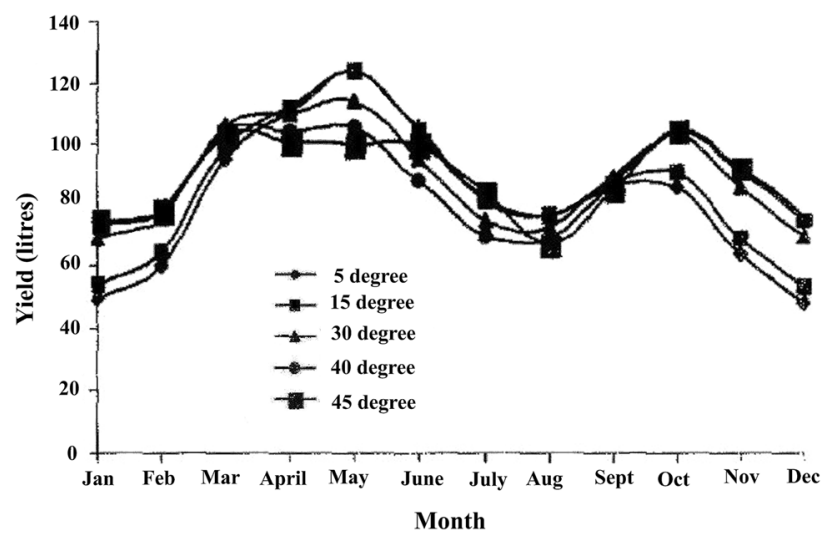

Fig. 9 Performance of solar still at different cover angles [26]

1. The volume of air between the water surface and condensing cover. The increasing slope will increase the volume of air to be saturated. This will reduce the productivity of the still.

2. An increase in the slope increases the amount of reflected radiations by the cover which reduces the yield of the still.

3. If the slope is too low, the speed of the droplets flowing on the inner surface of the cover will reduce. This will increase the chances of droplets falling in the basin instead of the condensate collector.

4. An increase in the slope will increase the surface area of the cover which means an increase in thermal losses.

Singh and Tiwari [26] investigated the annual yield of active and passive solar stills with varying climatic conditions at different locations and found that maximum yield is achieved when the slope of the cover is same as the latitude of the place. The results for these locations are shown in Fig. 9. Khalifa and Mahmood [20] discovered that by varying the slope of glass cover alone could alter the productivity of a still by approximately $63 \%$. Bilal et al. [27] investigated five different tilt angles of condensing cover of a solar still $\left(15^{\circ}, 25^{\circ}, 35^{\circ}, 45^{\circ}\right.$ and $\left.55^{\circ}\right)$ at Jordan (latitude $30^{\prime} 58^{\circ}$ ) and found out that highest yield occurred at $35^{\circ}$.
Velmurugan et al. [28] conducted experiments by inclining the cover plate at $10^{\circ}$ at Madurai (latitude $9^{\prime} 92$ ) and found promising results. Some of the researchers kept a different slope than the latitude. Al-hassan and Algarni [29] carried out experiments on a single basin solar still with an inclination of $45^{\circ}$ at Syria (latitude 34'80). Ehssan et al. [30] kept the inclination at $30^{\circ}$ in Egypt (latitude 26'82). Thus, the slope of the glass cover in the range of latitude angle $\pm 10^{\circ}$ was deemed permissible by many researchers. For places with higher latitude than $20^{\circ}$, only single slope stills are preferable since in double slope still, one side will remain shaded for most of the time [31, 32]. Based on the review, the glass cover inclination close to the latitude of the location would be optimum to absorb maximum radiation.

\subsection{Thickness of the cover}

The selective transmissivity of glass to transmit high frequency (high energy) radiation while blocking low frequency radiations makes it an excellent cover material for a solar still [33]. Ghoneyem and lleri [6] experimented on a solar still by varying the glass cover thickness by 3,5 and $6 \mathrm{~mm}$ and found that using a $3 \mathrm{~mm}$ thick glass cover, the highest yield is obtained. As glass is a heat insulator, more thickness of glass will reduce the heat transfer from the top surface of the glass to the inside of the still; hence there will be a limit to the temperature achieved by the water present inside. However, a very thin layer will reduce the condensation rate at the glass cover. The glass cover thickness in the range of 3-5 $\mathrm{mm}$ has been found as optimal by many researchers [34-36].

\subsection{Material of the cover}

The transmissivity of the cover material is an important parameter as discussed in the previous section. Other than that, the thermal conductivity of the cover also influences the yield of the solar still. Dimri et al. [37] investigated the yield of a solar still with three different condensing covers, namely copper, glass and plastic. The maximum yield was observed in the case of copper and minimum yield in the case of plastic as shown in Fig. 10. But, due to the 


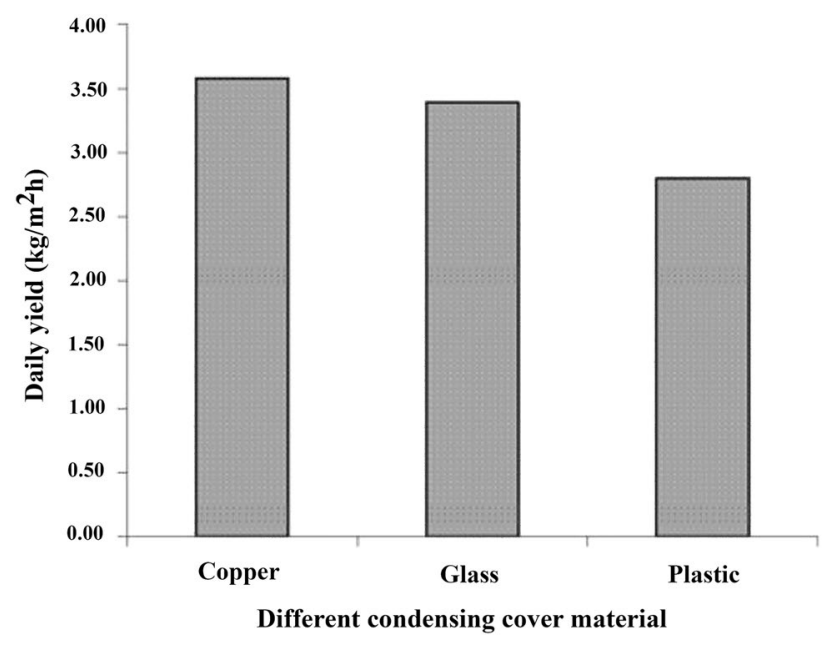

Fig. 10 Effect of various cover material on the yield of solar still [37]

vast cost difference between glass and copper, for a more cost-effective solar still, glass condensing cover is justified. However, there is very limited literature available on the effect of material cover and this area could be further explored.

\subsection{Water-glass cover temperature difference}

As the heat transfer between two surfaces is directly proportional to the temperature difference between them, the water-glass cover temperature difference is a major driving force for the mechanism of a solar still. AbuHijleh [38] cooled the top of the glass cover with water and observed a $6 \%$ increase in the efficiency of the still. Mousa [39] also observed a $20 \%$ increase in the efficiency of solar still by the use of water cooling film on the glass cover. Al-Garni [40] increased the temperature of the water by using a heater and observed a $370 \%$ enhancement in the productivity of the still due to the increased temperature difference between water and glass cover. Murugavel et al. [41] also used an electric resistance heater to heat the water and found an increase in productivity as the temperature difference is increased. Increased temperature of the water will increase the evaporation rate and the reduced temperature of glass cover will increase the condensation rate on its inner surface. Therefore, higher the water-glass cover temperature difference, more will be the productivity of the still.

\subsection{Insulation material and thickness}

During sunlight absorption, excess heat energy is absorbed by the basin water of a solar still. Unless there is proper insulation, this excess energy will be lost from the sides of the basin as waste heat. Hashim et al. [42]

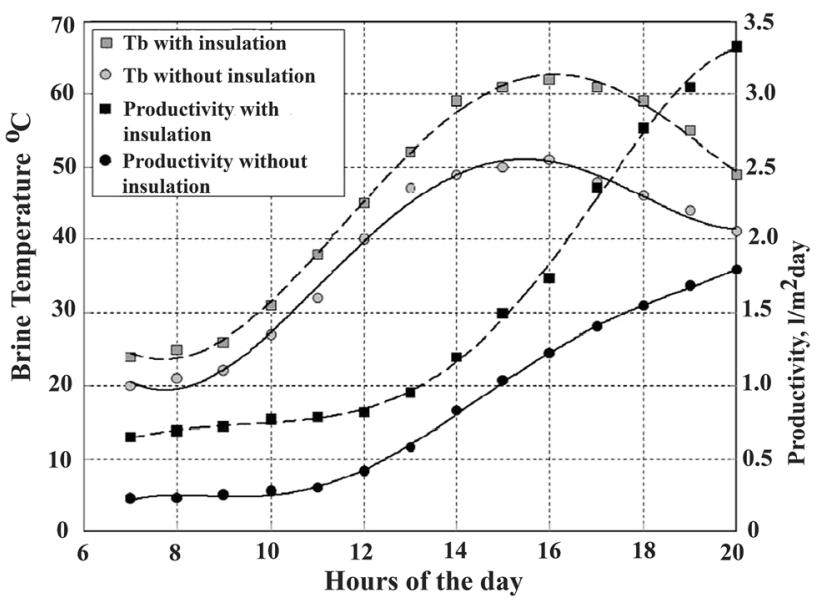

Fig. 11 Effect of insulation on productivity and brine temperature [45]

fabricated five different types of solar stills, one without insulation and other four with plywood, glasswool-plywood, hay-plywood and $5 \mathrm{~mm}$ thick air gap as insulation. The productivities of solar stills were found to increase by $82 \%, 130 \%, 126 \%$ and $74 \%$, respectively for stills with insulation compared to uninsulated solar still. Karaghouli and Alnaser [43] reported an increase of 15\% in the monthly average daily output of a solar still by the use of insulation. Sahoo et al. [14] observed that thermocol as an insulation material increases the efficiency by $11 \%$. Styrofoam, Polyurethane, wooden box with saw dust [21, 27, 44] have also been used as insulation materials by many researchers. Khalifa and Hamood [45] reported that proper insulation thickness can increase the efficiency of a still by $80 \%$. The effect of insulation on productivity and brine temperature is depicted in Fig. 11. Abdallah and Badran [46] investigated different insulation thickness in a solar still and found that the productivity of still with $6 \mathrm{~cm}$ thick insulation increased by $80 \%$ in comparison to $3 \mathrm{~cm}$ thick insulation. This is because the increased thickness of the insulation reduces the heat loss to the surroundings and the heat is supplied back to the water. In view of these findings, proper insulating materials should be used for the reduction of thermal losses from the sides and the base of the solar still.

\subsection{Surface area of evaporation}

Alaudeen et al. [12] reported that the productivity of solar still is directly proportional to the free surface area of the water as it increases the evaporation rate. More surface area means more absorber area that is exposed to direct sunlight, hence more increase in temperature of the water. Velumurugan et al. [47] integrated fins with solar stills to 
enlarge the surface area and reported an improvement of $30 \%$ in the average daily production. Other studies have also confirmed this conclusion [48]. Kwatra [49] introduced multiple basins in a greenhouse type solar still to increase the area of evaporation and observed an increase of $19.6 \%$ in the productivity of solar cells. Different methods to increase the evaporation area have been discussed further in the review.

\section{Design modifications in solar stills to enhance the effect of design parameters}

The performance of the solar stills can be enhanced by varying some operational parameters like increasing the inlet water temperature or by modification in the design of the still, the use of external and internal reflectors, stepped basin, use of wicks or coupling of external heating source.

\subsection{Use of energy storage materials}

The intermittent nature of solar energy makes it imperative that energy storage methods should be employed to increase the productivity of the still when there is no sunlight, especially at nights. Nocturnal productivity in a solar still can be enhanced by the usage of energy storage materials at the base like sand, gravel, rock pebbles. Ward [50] used black polycarbonate as an energy absorbing material at the bottom of the still and observed high productivity. Naim and El Kawi [51] found that charcoal bed at the basin enhanced the productivity by $15 \%$. Naim and El Kawi [52] also performed experiments using phase change materials as energy absorbing material and found a significant increase in productivity. Tabrizi et al. [53] investigated the use of paraffin wax as an energy storage material in a weirtype cascade solar still. While the daily productivity of the still with paraffin was lesser than that without paraffin, the nocturnal productivity of the former still was found to be higher. Shalaby et al. [54] also reported that the use of paraffin in a still with v-corrugated absorber increases the nocturnal productivity by $72.7 \%$. The modified still is presented in Fig. 12. Velmurugan et al. [55] found that the pebbles are suitable energy storage materials in a solar still as they are a good absorber of energy during sunlight and release it at night. Hitesh [56] reported a $65 \%$ increase in the distillate output by the use of black granite gravel. The use of black gravel and rubber as energy storage materials have been reported by Nafey [57] to increase the productivity by $19 \%$ and $20 \%$ respectively. Omara and Kabeel [58] investigated different types of sands as energy storage materials and found $42 \%$ enhancement by the use of black sand beds.

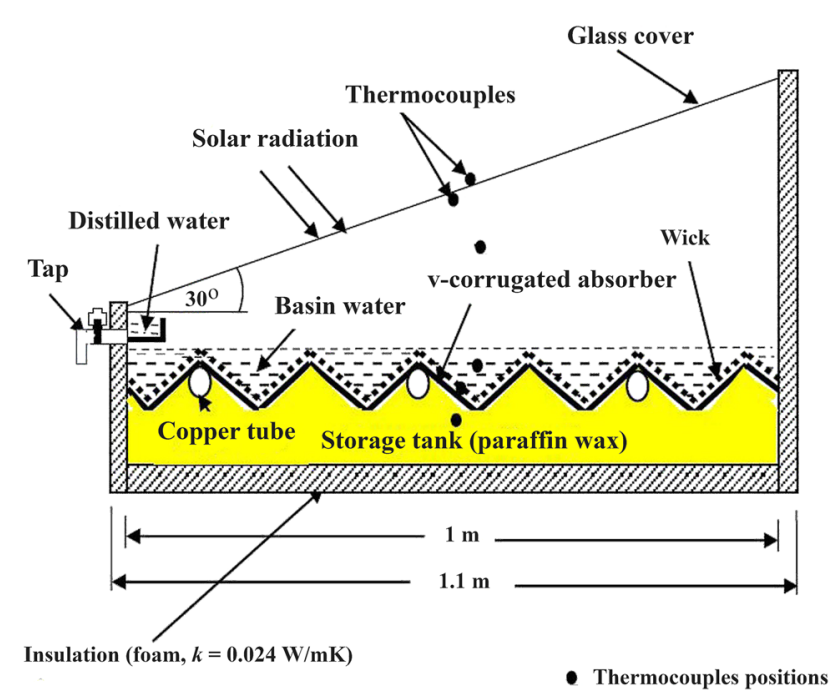

Fig. 12 Corrugated absorber single-basin solar still using PCM [54]

\subsection{Use of porous materials}

Usage of porous materials as absorber surfaces in solar still makes its top surface wet due to capillary effect due to which a thin layer of water is formed on the top. A thin layer of water means higher surface to volume ratio which helps in raising the water temperature quickly, consequently resulting in more productivity. Most of the solar still employing porous materials are known as wick-type still. Arunkumar et al. [59] introduced carbon impregnated foam in a still and found a $35 \%$ increase in the productivity. Nafey et al. [60] reported a productivity increase of $15 \%$ and $40 \%$ at a brine depth of $3 \mathrm{~cm}$ and $6 \mathrm{~cm}$, respectively by the use of a floating black perforated plate of aluminum. Rashidi et al. [61] observed the use of a reticular porous layer in the still which increases hourly productivity and efficiency. Abdallah et al. [62] investigated three different porous materials, namely coated metallic, uncoated metallic wiry sponge and black rocks and found nocturnal yield enhancement by $28 \%, 43 \%$ and $60 \%$ respectively. Minasian and Al-Karaghouli [63] found that use of a blackened jute cloth increases the productivity by $85 \%$. Sengar et al. [64] also obtained a higher yield by using jute cloth. Some studies have also reported black light cotton cloth as an effective productivity enhancer for solar stills [65-67]. Omara et al. [68] reported about a $90 \%$ increase in productivity by the use of a corrugated wick.

\subsection{Use of reflectors}

Reflectors are inexpensive and beneficial in increasing the distillate yield of a solar still. They are used to concentrate the solar radiation on the desired area which increases the heat flux received by that area. Waste heat energy from 
the still is also reduced by the use of reflectors [69]. Many types of external and internal reflectors have been used by the researchers for increasing the efficiency of the stills [36]. Tamini [70] reported that the efficiency of a still can be increased by installing mirrors on its side walls. The efficiency curve of a solar still with reflectors is presented in Fig. 13. Abdallah et al. [71] found that by using mirrors on the internal walls, the thermal performance of the still was

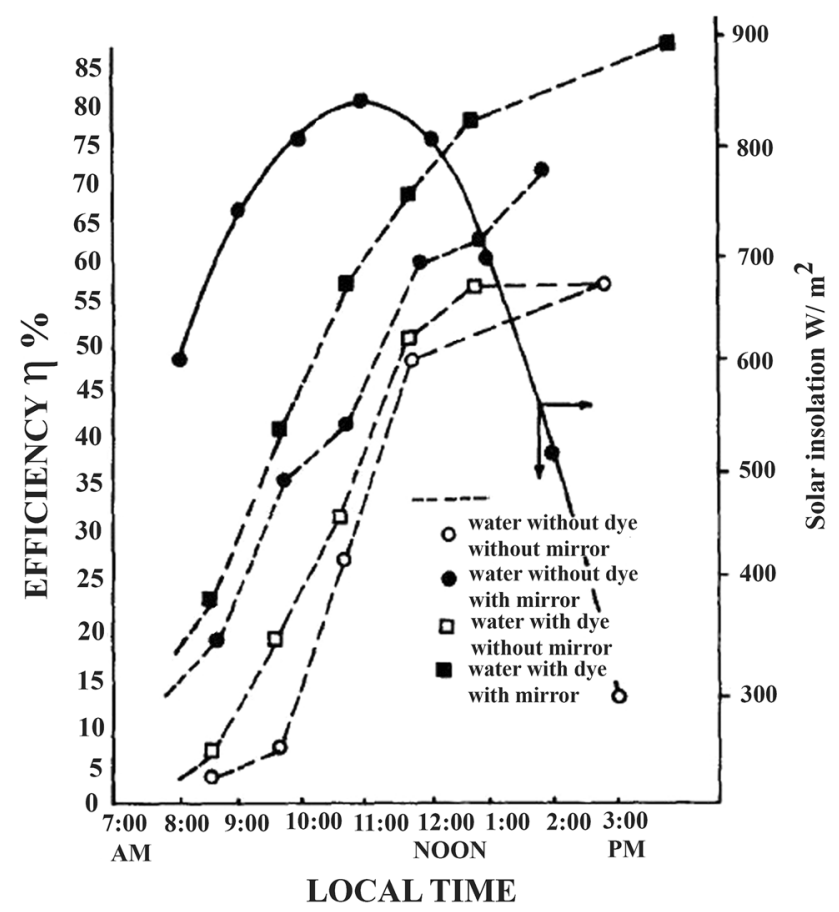

Fig. 13 Effect of reflectors on the efficiency of solar still [70] improved by $30 \%$. Karimi et al. [72] performed numerical modelling of a still with internal reflectors on front and side walls and observed an $18 \%$ increase in the efficiency. The efficiency of a stepped solar still of $53 \%$ was increased to $56 \%$ by the use of internal reflectors [73]. Tanaka and Nakatake [74] investigated the effect of a vertical flat plate external reflector on a tilted wick solar still and found a $9 \%$ enhancement in the productivity. In another analysis by Tanaka and Nakatake [75], it is reported that a simple modification of adding a reflector with one-step azimuth tracking could increase the productivity of tilted wick solar still by $41 \%$. Shanmugan et al. [76] used an external acrylic mirror to boost the performance of a solar still. The setup is depicted in Fig. 14. The mirror can be adjusted to the sun angle and it reflects the excess radiation to the water. The still efficiency was found to increase by $45 \%$. El-Samodany [77] conducted an experimental study on a stepped solar still with internal and external reflectors and found a $165 \%$ increase in distillate production in comparison to conventional still. Khalifa and Ibrahim [78] reported that the use of an internal reflector and a combination of the internal and external reflectors can boost the productivity of a solar still by $19.9 \%$ and $35.5 \%$, respectively.

\subsection{Use of fins}

The utilization of fins in the solar stills has been found to cause a significant improvement in their performance. Preheating time for the brine reduces due to the extended evaporation surface area and an increase in the absorber area. Velmurugan et al. [28] observed a $45 \%$ increase in the productivity of the stills by the use of fins. Alaian et al. [79] investigated the use of pin fins in a solar still and reported
Fig. 14 Solar still with internal and external reflectors [76]

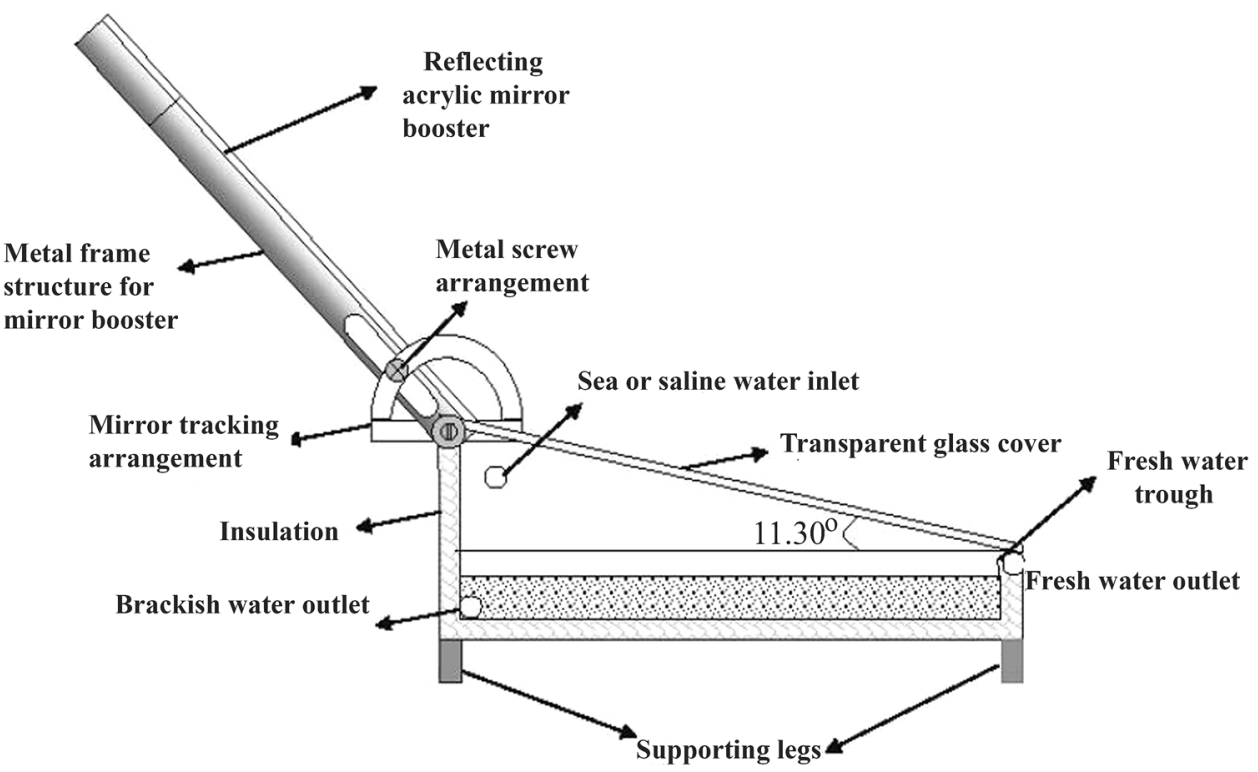


a productivity rise of $23 \%$. Ayuthaya et al. found use of fins increases the productivity of the still by $15.5 \%$ compared to the conventional still [80]. Srivastava and Agrawal [81] reported that winter and summer yield of solar stills with the fin is $15 \%$ and $48 \%$ higher respectively than the conventional solar stills. The effect of fins on the component temperature during winter and summer is shown in Fig. 15.

\subsection{Use of integrated structures}

Researchers have coupled a number of external devices and processes with the solar still to increase their thermal performance which leads to an increase in productivity. The integration of various improvement technologies has been done to increase the yield of a solar still. Tiris et al. [82] conducted an experimental analysis on a solar still by using a flat plate collector and found that the yield was increased by about $100 \%$. Rai and Tiwari [83] combined a flat plate collector with a solar still and observed a $24 \%$ enhancement in the daily productivity. The schematic of a solar distillation unit with a flat plate collector is shown in Fig. 16. Another design of a parabolic shaped concentrator integrated with solar stills has also been found to increase its performance [84]. The schematic of this design is presented in Fig. 17. Abdel-Rehim et al. [85] modified
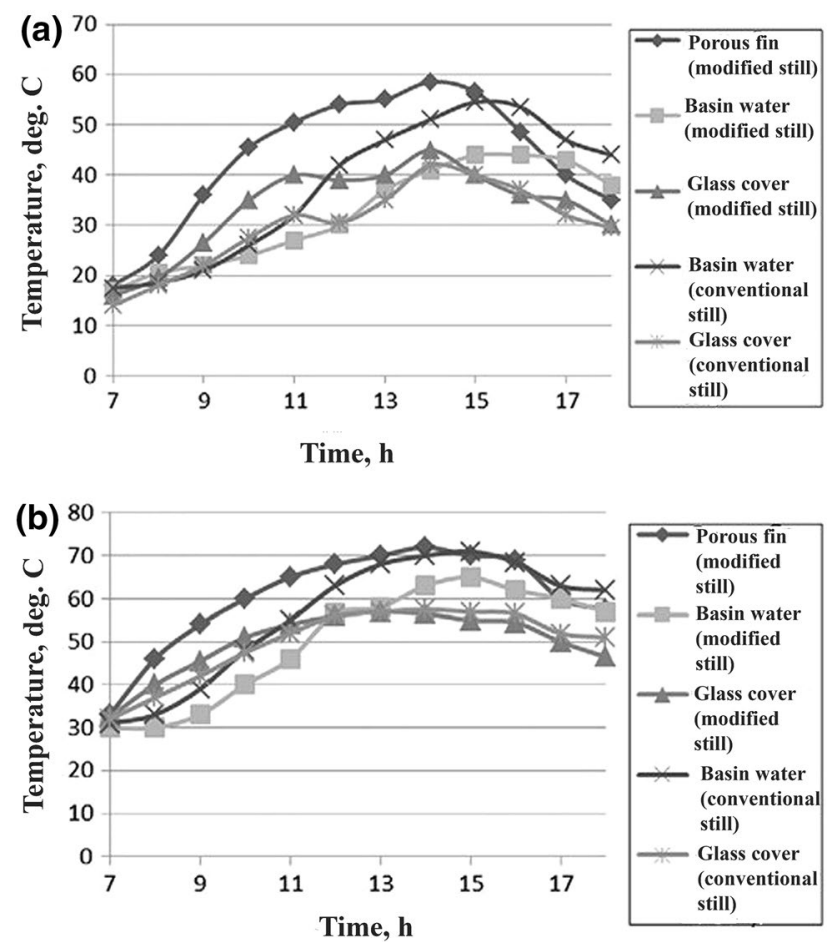

Fig. 15 Effect of fin on the yield of solar stills in $\mathbf{a}$ winter and $\mathbf{b}$ summer [81]

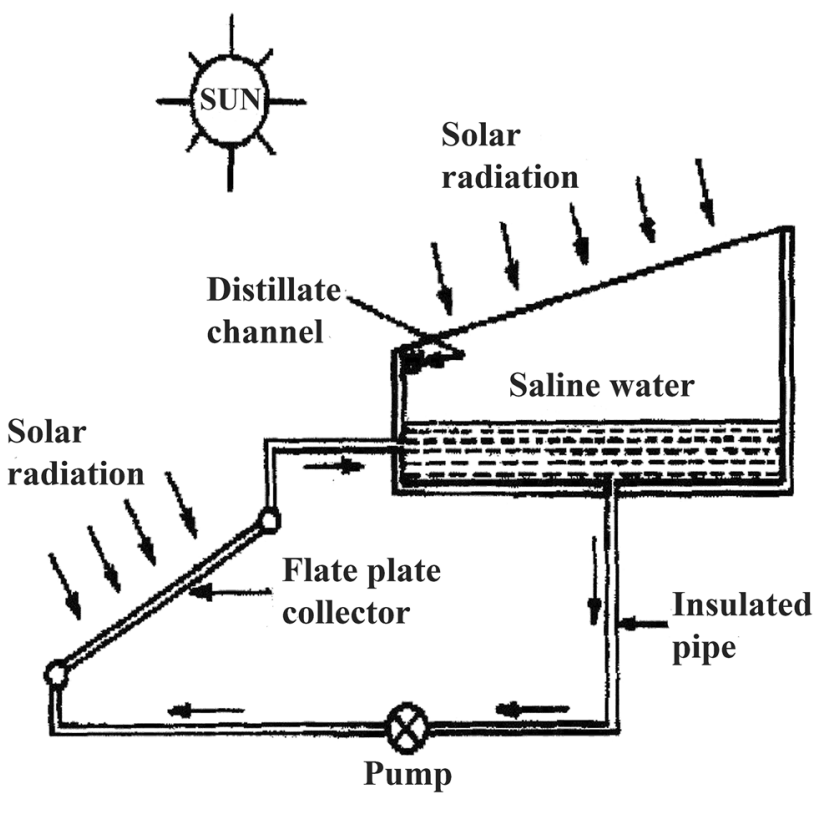

Fig. 16 Schematic of a solar still with flat plate collector [26]

the design of a solar still by integrating a parabolic trough collector, a simple heat exchanger and a focal pipe. A productivity enhancement of $18 \%$ is observed over the conventional still. Shafii et al. [86] coupled a conventional solar still with evacuated tube collectors (ETC) and thermoelectric modules. The use of ETC increased the yield of the system by $5 \%$. Kumar et al. [87] developed a thermal model of a solar still integrated with ETC and predicted an improved performance. Figure 18 shows the schematic of this model. The integration of heat pipes to the solar still is used to transfer the heat to it, which increases evaporation and hence productivity [88]. Abad et al. [89] integrated pulsating heat pipes as a high performing thermal device to a solar still and observed remarkable production rate. Figure 19 shows the setup with pulsating heat pipes. El-Sebaii et al. [90] coupled a conventional solar still to a shallow solar pond in Tanta (latitude 30'47). Numerical and experimental analysis was carried out with

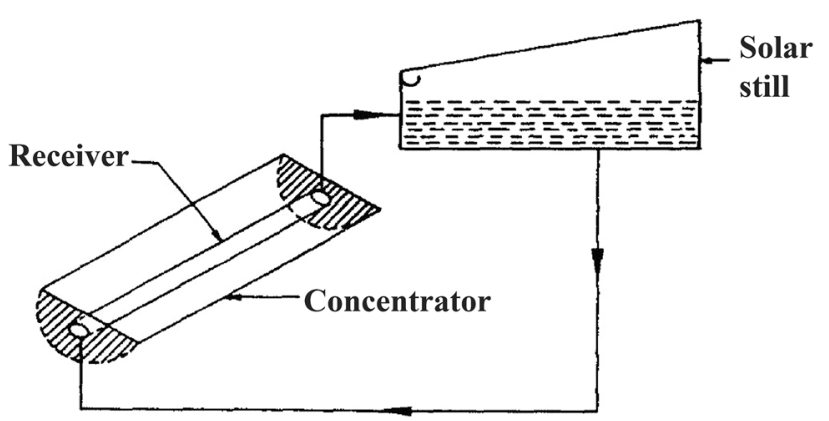

Fig. 17 Solar stills integrated with parabolic concentrator [84] 
Fig. 18 Solar still integrated with evacuated tube collector [87]

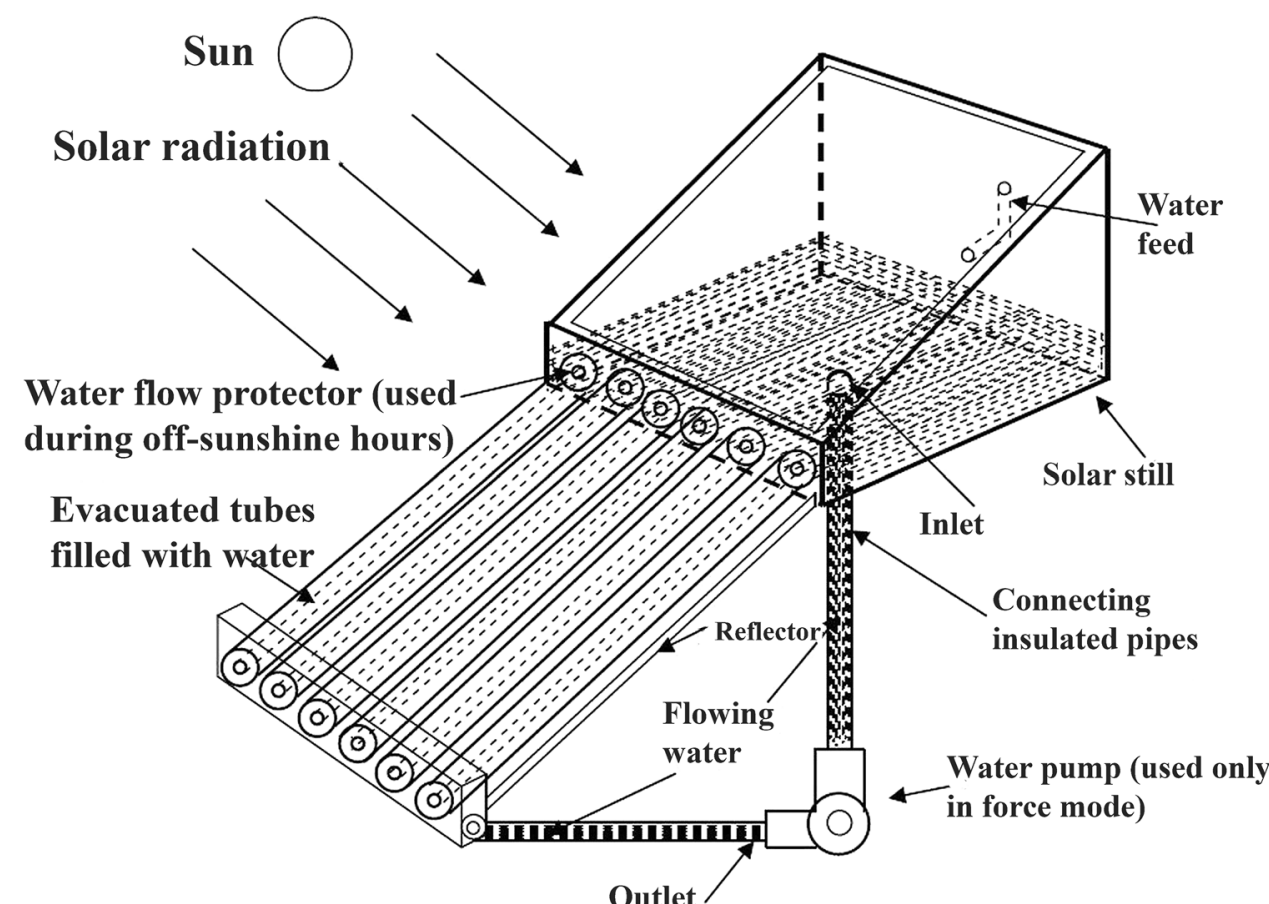

Outlet

a good agreement. The daily productivity was found to be enhanced by $52.36 \%$. Velmurugan and Srithar [91] also integrated a solar pond to the conventional still and the productivity increased by $27.6 \%$. The schematic of the setup and the results obtained are shown in Fig. 20. Integration with solar pond increases the temperature difference between the glass cover and basin water which results in a higher rate of heat transfer.

Fig. 19 Pulsating heat pipe coupled with solar still [89]

(a)

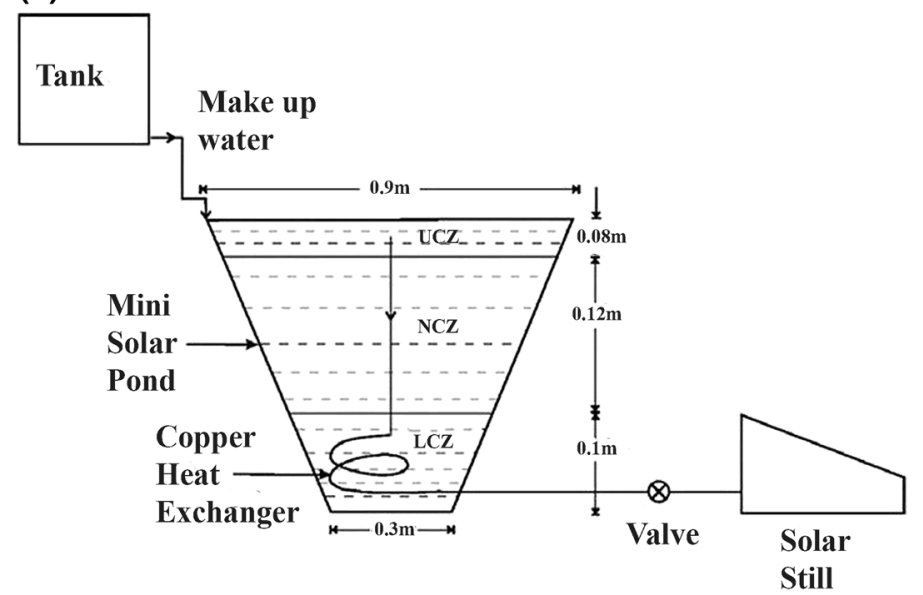

(b)

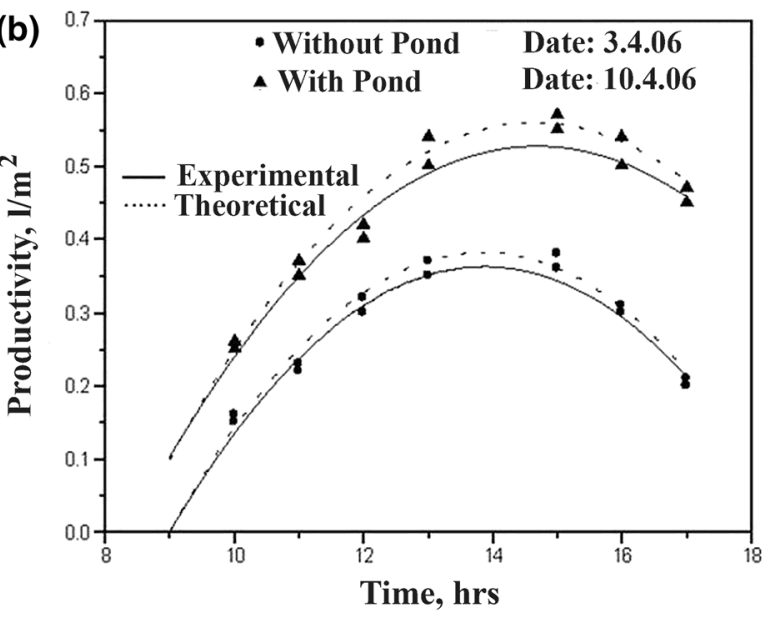

Fig. 20 a Solar pond integrated solar still and b Effect on productivity [91] 
Table 2 Literature on the modifications in solar stills and their effects on the productivity/efficiency of solar stills

\begin{tabular}{|c|c|c|c|c|c|c|}
\hline S. no. & Type of solar still & Location/latitude & Tilt angle & Temperature $\left({ }^{\circ} \mathrm{C}\right)$ & $\begin{array}{l}\text { Integration/modified } \\
\text { parameter }\end{array}$ & Effect \\
\hline 1 & $\begin{array}{l}\text { Single slope single } \\
\text { basin [37] }\end{array}$ & New Delhi $\left(28^{\circ} 35^{\prime} N\right)$ & $28.35^{\circ}$ & 19 & $\begin{array}{l}\text { Flat plate collector, } \\
\text { condensing cover }\end{array}$ & $\begin{array}{l}\text { Daily yield increases by } \\
6 \%\end{array}$ \\
\hline 2 & $\begin{array}{l}\text { Single slope single } \\
\text { basin [38] }\end{array}$ & Irbid $\left(32^{\circ} 55^{\prime} \mathrm{N}\right)$ & - & 30 & Cooling of glass cover & $6 \%$ increase in efficiency \\
\hline 3 & $\begin{array}{l}\text { Single slope single } \\
\text { basin [39] }\end{array}$ & Irbid $\left(32^{\circ} 55^{\prime} \mathrm{N}\right)$ & - & 30 & Cooling of glass cover & $20 \%$ increase in efficiency \\
\hline 4 & $\begin{array}{l}\text { Double slope single } \\
\text { basin [40] }\end{array}$ & Dhahran $\left(26^{\circ} \mathrm{N}\right)$ & $35^{\circ}$ & 25 & Heater in the basin & $\begin{array}{l}370 \% \text { increase in produc- } \\
\text { tivity }\end{array}$ \\
\hline 5 & $\begin{array}{l}\text { Single slope single } \\
\text { basin/double basin } \\
{[43]}\end{array}$ & Isa Town $\left(26^{\circ} 16^{\prime} \mathrm{N}\right)$ & $36^{\circ}$ & 26 & Styrobore Insulation & $\begin{array}{l}15 \% \text { increase in monthly } \\
\text { daily output }\end{array}$ \\
\hline 6 & $\begin{array}{l}\text { Single slope single } \\
\text { basin [46] }\end{array}$ & Amman $\left(31^{\circ} 95^{\prime} \mathrm{N}\right)$ & $32^{\circ}$ & 30 & Sun tracking system & $\begin{array}{l}22 \% \text { productivity } \\
\text { enhancement }\end{array}$ \\
\hline 7 & $\begin{array}{l}\text { Greenhouse multi basin } \\
\text { [49] }\end{array}$ & Chennai $\left(13^{\circ} 08^{\prime} \mathrm{N}\right)$ & - & 38 & Evaporation area & $19.6 \%$ gain in yield \\
\hline 8 & $\begin{array}{l}\text { Single slope single } \\
\text { basin [59] }\end{array}$ & Chennai $\left(13^{\circ} 08^{\prime} \mathrm{N}\right)$ & $13^{\circ}$ & 38 & $\begin{array}{l}\text { carbon impregnated } \\
\text { foam }\end{array}$ & $\begin{array}{l}35 \% \text { productivity } \\
\text { enhancement }\end{array}$ \\
\hline 9 & $\begin{array}{l}\text { Single slope single } \\
\text { basin [70] }\end{array}$ & Irbid $\left(32^{\circ} 55^{\prime} \mathrm{N}\right)$ & $45^{\circ}$ & 30 & $\begin{array}{l}\text { Mirrors on side walls } \\
\text { and black dye }\end{array}$ & $\begin{array}{l}\text { Increase in hourly pro- } \\
\text { ductivity }\end{array}$ \\
\hline 10 & $\begin{array}{l}\text { single slope stepped } \\
\text { basin [77] }\end{array}$ & Kafr El-Sheikh $\left(31^{\circ} 11^{\prime} \mathrm{N}\right)$ & $30^{\circ}$ & 18 & $\begin{array}{l}\text { Reflectors and con- } \\
\text { denser }\end{array}$ & $165 \%$ higher productivity \\
\hline 11 & $\begin{array}{l}\text { Single slope single } \\
\text { basin [79] }\end{array}$ & Mansoura $\left(31^{\circ} 04^{\prime} \mathrm{N}\right)$ & $17^{\circ}$ & - & Pin-finned wick & $\begin{array}{l}23 \% \text { increase in produc- } \\
\text { tivity }\end{array}$ \\
\hline 12 & $\begin{array}{l}\text { single slope single } \\
\text { basin [91] }\end{array}$ & Madurai $\left(9^{\circ} 92^{\prime} \mathrm{N}\right)$ & $10^{\circ}$ & 30 & Solar pond integration & $\begin{array}{l}7.8 \% \text { productivity } \\
\text { enhancement }\end{array}$ \\
\hline 13 & $\begin{array}{l}\text { Single Slope Single } \\
\text { Basin [92] }\end{array}$ & Jordan $\left(30^{\circ} 58^{\prime} \mathrm{N}\right)$ & $35^{\circ}$ & 20 & Flat plate collector & $\begin{array}{l}\text { Productivity increases } \\
\text { by } 36 \%\end{array}$ \\
\hline 14 & $\begin{array}{l}\text { Single SLOPE SINGLE } \\
\text { BASIN [93] }\end{array}$ & Baghdad $\left(33^{\circ} 31^{\prime} \mathrm{N}\right)$ & $30^{\circ}$ & 28 & $\begin{array}{l}\text { Double pass internal } \\
\text { condenser }\end{array}$ & $\begin{array}{l}\text { Productivity increases } \\
\text { by } 7 \%\end{array}$ \\
\hline 15 & $\begin{array}{l}\text { Passive double slope } \\
\text { single basin [94] }\end{array}$ & New Delhi $\left(28^{\circ} 35^{\prime} N\right)$ & $30^{\circ}$ & 25 & $\begin{array}{l}\text { Addition of nanopar- } \\
\text { ticles }\end{array}$ & $\begin{array}{l}\text { Daily yield increases by } \\
12.2 \%\end{array}$ \\
\hline 16 & $\begin{array}{l}\text { Hemishpherical single } \\
\text { basin [95] }\end{array}$ & Coimbatore $\left(11^{\circ} \mathrm{N}\right)$ & - & 32 & $\begin{array}{l}\text { Hemispherical top } \\
\text { cover }\end{array}$ & $\begin{array}{l}\text { Efficiency enhanced to } \\
42 \%\end{array}$ \\
\hline 17 & $\begin{array}{l}\text { Single slope single } \\
\text { basin [96] }\end{array}$ & $11^{\circ} \mathrm{N}$ & $25^{\circ}$ & - & Energy storage material & $20 \%$ increase in yield \\
\hline 18 & $\begin{array}{l}\text { Single slope single } \\
\text { basin [97] }\end{array}$ & $23^{\circ} 12^{\prime}$ & $30^{\circ}$ & - & Glass cover Thickness & $\begin{array}{l}\text { Lower glass cover thick- } \\
\text { ness increases yield }\end{array}$ \\
\hline 19 & $\begin{array}{l}\text { Double slope single } \\
\text { basin [98] }\end{array}$ & Jordan $\left(30^{\circ} 58^{\prime} \mathrm{N}\right)$ & $35^{\circ}$ & 25 & $\begin{array}{l}\text { Absorber material } \\
\text { (black dye) }\end{array}$ & $\begin{array}{l}\text { Productivity enhance- } \\
\text { ment of } 60 \%\end{array}$ \\
\hline 20 & $\begin{array}{l}\text { Double slope single } \\
\text { basin [99] }\end{array}$ & $\begin{array}{l}\text { Wadi El-dwaser }\left(21^{\circ} 5^{\prime}\right. \\
\mathrm{N})\end{array}$ & $30^{\circ}$ & - & $\begin{array}{l}\text { Vibratory harmonic } \\
\text { effect }\end{array}$ & $\begin{array}{l}\text { Productivity increases } \\
\text { by } 70 \%\end{array}$ \\
\hline 21 & $\begin{array}{l}\text { Single slope single } \\
\text { basin [100] }\end{array}$ & Irbid $\left(32^{\circ} 55^{\prime} \mathrm{N}\right)$ & $23^{\circ}$ & $21^{\circ} \mathrm{C}$ & Sponge cubes & $\begin{array}{l}273 \% \text { increase in still } \\
\text { production }\end{array}$ \\
\hline 22 & $\begin{array}{l}\text { Single slope single } \\
\text { basin [101] }\end{array}$ & Tanta $\left(30^{\circ} 78^{\prime} \mathrm{N}\right)$ & $15^{\circ}$ & - & Finned basin liner & $\begin{array}{l}13.7 \% \text { higher productiv- } \\
\text { ity }\end{array}$ \\
\hline 23 & $\begin{array}{l}\text { Single slope single } \\
\text { basin [102] }\end{array}$ & Amman $\left(31^{\circ} 95^{\prime} \mathrm{N}\right)$ & $32^{\circ}$ & 30 & $\begin{array}{l}\text { Asphalt basin and } \\
\text { sprinkler }\end{array}$ & $\begin{array}{l}51 \% \text { productivity } \\
\text { increase }\end{array}$ \\
\hline 24 & $\begin{array}{l}\text { Double slope single } \\
\text { basin [103] }\end{array}$ & Sohag $\left(26^{\circ} 33^{\prime} N\right)$ & $26.5^{\circ}$ & - & $\begin{array}{l}\text { Parabolic trough col- } \\
\text { lector }\end{array}$ & $\begin{array}{l}89 \% \text { increase in summer } \\
\text { productivity }\end{array}$ \\
\hline 25 & $\begin{array}{l}\text { Single slope single } \\
\text { basin [104] }\end{array}$ & & $35^{\circ}$ & - & $\begin{array}{l}\text { PCM absorber and flat } \\
\text { plate collector }\end{array}$ & $\begin{array}{l}\text { Nocturnal productivity } \\
\text { increased }\end{array}$ \\
\hline 26 & $\begin{array}{l}\text { Single slope single } \\
\text { basin [105] }\end{array}$ & $\left(30^{\circ} 78^{\prime} \mathrm{N}\right)$ & $30.47^{\circ}$ & - & $\begin{array}{l}\text { Graphite absorbing } \\
\text { material }\end{array}$ & $\begin{array}{l}80.05 \% \text { increase in daily } \\
\text { productivity }\end{array}$ \\
\hline
\end{tabular}


Table 2 (continued)

\begin{tabular}{|c|c|c|c|c|c|c|}
\hline S. no. & Type of solar still & Location/latitude & Tilt angle & Temperature $\left({ }^{\circ} \mathrm{C}\right)$ & $\begin{array}{l}\text { Integration/modified } \\
\text { parameter }\end{array}$ & Effect \\
\hline 27 & $\begin{array}{l}\text { Pyramidal single basin } \\
\text { [106] }\end{array}$ & Chennai $\left(13^{\circ} 08^{\prime} \mathrm{N}\right)$ & $30^{\circ}$ & 38 & Fresnel lens & $\begin{array}{c}\text { Faster reduction in } \mathrm{pH} \text { of } \\
\text { contaminated water }\end{array}$ \\
\hline 28 & $\begin{array}{l}\text { Single slope single } \\
\text { basin [107] }\end{array}$ & Borg El-Arab $\left(30^{\circ} 91^{\prime} \mathrm{N}\right)$ & $31^{\circ}$ & 32 & $\begin{array}{l}\text { forced air cooing with } \\
\text { PV and PCM }\end{array}$ & $\begin{array}{l}\text { Daily yield increases by } \\
19.4 \%\end{array}$ \\
\hline 29 & $\begin{array}{l}\text { Single slope single } \\
\text { basin [108] }\end{array}$ & Baghdad $\left(33^{\circ} 31^{\prime} \mathrm{N}\right)$ & $30^{\circ}$ & 28 & $\begin{array}{l}\text { Nanoparticle enhanced } \\
\text { PCM }\end{array}$ & $60.53 \%$ increase in yield \\
\hline
\end{tabular}

\section{Conclusions}

A review of research works dealing with different modifications in solar stills for the improvement of their productivity is carried out. A summary of the works studied for this review with modifications and their effects are presented in Table 2. The major conclusions of this review are as follows:

- The reduction of basin water depth increases the rate of evaporation, consequently increasing productivity.

- The cover tilt angle and direction also play important roles. The cover inclination angle equal to the latitude angle of location receives maximum solar radiation. It helps in getting maximum yield from the still.

- The optimum thickness of insulation according to the design of the still reduces the heat loss and increase the thermal efficiency of the still.

- Porous absorber materials in the basins increase the yield by as much as $273 \%$.

- Sun tracking system is efficient in improving the performance of the system.

- The integration of solar still with heat exchangers or collectors increases the thermal efficiency and productivity of the system.

- $165 \%$ increase in productivity can be obtained by using reflectors and condensers.

Acknowledgements The authors would like to thank Material Research Laboratory, Physics Department of Sharda University, U.P. India and Amity University, Dubai.

\section{Compliance with ethical standards}

Conflict of interest The authors declare that there is no conflict of interest.

\section{References}

1. Kabeel AE (2009) Performance of solar still with a concave wick evaporation surface. Energy 34(10):1504-1509

2. Lee HJ, Sarfert F, Strathmann H, Moon SH (2002) Designing of an electrodialysis desalination plant. Desalination 142(3):267-286

3. Greenlee LF, Lawler DF, Freeman BD, Marrot B, Moulin P (2009) Reverse osmosis desalination: water sources, technology, and today's challenges. Water Res 43(9):2317-2348

4. Tiwari AK, Tiwari GN (2007) Thermal modeling based on solar fraction and experimental study of the annual and seasonal performance of a single slope passive solar still: the effect of water depths. Desalination 207(1-3):184-204

5. Velmurugan V, Kumaran SS, Prabhu VN, Srithar K (2008) Productivity enhancement of stepped solar still-performance analysis. Therm Sci 12(3):153-163

6. Ghoneyem A, lleri A (1997) Software to analyze solar stills and an experimental study on the effects of the cover. Desalination 114(1):37-44

7. Singh AK, Tiwari GN, Sharma PB, Khan E (1995) Optimization of orientation for higher yield of solar still for a given location. Energy Convers Manag 36(3):175-181

8. Zurigat YH, Abu-Arabi MK (2004) Modelling and performance analysis of a regenerative solar desalination unit. Appl Therm Eng 24(7):1061-1072

9. Tiwari GN, Thomas JM, Khan E (1994) Optimisation of glass cover inclination for maximum yield in a solar still. Heat Recovery Syst CHP 14(4):447-455

10. El-Sebaii AA (2000) Effect of wind speed on some designs of solar stills. Energy Convers Manag 41(6):523-538

11. Tiwari GN, Garg HP (1985) Effect of water flow over the glass cover of a single basin solar still with an intermittent flow of waste hot water in the basin. Energy Convers Manag 25(3):315-322

12. Alaudeen A, Johnson K, Ganasundar P, Abuthahir AS, Srithar K (2014) Study on stepped type basin in a solar still. J King Saud Univ-Eng Sci 26(2):176-183

13. Madhukeshwara N, Prakash ES (2012) An investigation on the performance characteristics of solar flat plate collector with different selective surface coatings. Int J Energy Environ 3(1):99-108

14. Sahoo BB, Sahoo N, Mahanta P, Borbora L, Kalita P, Saha UK (2008) Performance assessment of a solar still using blackened surface and thermocol insulation. Renew Energy 33(7):1703-1708

15. Mahdi JT, Smith BE, Sharif AO (2011) An experimental wicktype solar still system: design and construction. Desalination 267(2-3):233-238

16. Taghvaei $H$, Taghvaei $H$, Jafarpur K, Estahbanati MK, Feilizadeh M, Feilizadeh M, Ardekani AS (2014) A thorough 
investigation of the effects of water depth on the performance of active solar stills. Desalination 347:77-85

17. Tiwari GN, Sumegha C, Yadav YP (1991) Effect of water depth on the transient performance of a double basin solar still. Energy Convers Manag 32(3):293-301

18. Elango T, Murugavel KK (2015) The effect of the water depth on the productivity for single and double basin double slope glass solar stills. Desalination 359:82-91

19. Rajamanickam MR, Ragupathy A (2012) Influence of water depth on internal heat and mass transfer in a double slope solar still. Energy procedia 14:1701-1708

20. Khalifa AJN, Hamood AM (2009) On the verification of the effect of water depth on the performance of basin type solar stills. Sol Energy 83(8):1312-1321

21. Aboul-Enein S, El-Sebaii AA, El-Bialy E (1998) Investigation of a single-basin solar still with deep basins. Renew Energy 14(1-4):299-305

22. Manokar AM, Murugavel KK, Esakkimuthu G (2014) Different parameters affecting the rate of evaporation and condensation on passive solar still-a review. Renew Sustain Energy Rev 38:309-322

23. Al-Hinai H, Al-Nassri MS, Jubran BA (2002) Effect of climatic, design and operational parameters on the yield of a simple solar still. Energy Convers Manag 43(13):1639-1650

24. Nafey AS, Abdelkader M, Abdelmotalip A, Mabrouk AA (2000) Parameters affecting solar still productivity. Energy Convers Manag 41(16):1797-1809

25. Aybar HŞ, Egelioğlu F, Atikol U (2005) An experimental study on an inclined solar water distillation system. Desalination 180(1-3):285-289

26. Singh HN, Tiwari GN (2004) Monthly performance of passive and active solar stills for different Indian climatic conditions. Desalination 168:145-150

27. Akash BA, Mohsen MS, Nayfeh W (2000) Experimental study of the basin type solar still under local climate conditions. Energy Convers Manag 41(9):883-890

28. Velmurugan V, Gopalakrishnan M, Raghu R, Srithar K (2008) Single basin solar still with fin for enhancing productivity. Energy Convers Manag 49(10):2602-2608

29. Al-hassan GA, Algarni SA (2013) Exploring of water distillation by single solar still basins. Am J Clim Change 2(01):57

30. Nassef, E. M., El-Abd, M. Z., \& El-Tawil, Y. A. (2013, February). Study of the performance of solar still". In 2nd International Conference on Energy Systems and Technologies (pp. 18-21)

31. Fath HE, El-Samanoudy M, Fahmy K, Hassabou A (2003) Thermal-economic analysis and comparison between pyramidshaped and single-slope solar still configurations. Desalination 159(1):69-79

32. Murugavel KK, Chockalingam KK, Srithar K (2008) Progresses in improving the effectiveness of the single basin passive solar still. Desalination 220(1-3):677-686

33. Lindblom, J. (2003). Solar thermal technologies for seawater desalination: state of the art. Renewable Energy Systems, Lulea ${ }^{\circ}$ University of Technology, Sweden

34. Naim, M. M., \& El Kawi, M. A. A. (2003). Non-conventional solar stills Part 1. Non-conventional solar stills with charcoal particles as absorber medium. Desalination, 153 (1-3), 55-64

35. Dev R, Tiwari GN (2009) Characteristic equation of a passive solar still. Desalination 245(1-3):246-265

36. Tanaka $\mathrm{H}$ (2009) Experimental study of a basin type solar still with internal and external reflectors in winter. Desalination 249(1):130-134

37. Dimri V, Sarkar B, Singh U, Tiwari GN (2008) Effect of condensing cover material on yield of an active solar still: an experimental validation. Desalination 227(1-3):178-189
38. Abu-Hijleh BA (1996) Enhanced solar still performance using water film cooling of the glass cover. Desalination 107(3):235-244

39. Mousa HA (1997) Water film cooling over the glass cover of a solar still including evaporation effects. Energy 22(1):43-48

40. Al-Garni AZ (2012) Enhancing the solar still using immersion type water heater productivity and the effect of external cooling fan in winter. Appl Sol Energy 48(3):193-200

41. Murugavel KK, Chockalingam KSK, Srithar K (2009) Modeling and verification of double slope single basin sol still using laboratory and actual solar conditions. JJMIE 3(3):228-235

42. Hashim AY, Al-Asadi JM, Taha WA (2009) Experimental investigation of symmetrical double slope single basin solar stills productivity with different Insulation. J Kufa-physics 1(2):26-32

43. Al-Karaghouli AA, Alnaser WE (2004) Performances of single and double basin solar-stills. Appl Energy 78(3):347-354

44. El-Bassuoni AMA (1986) Enhanced solar desalination unit: modified cascade still. Sol wind technol 3(3):189-194

45. Khalifa AJN, Hamood AM (2009) Effect of insulation thickness on the productivity of basin type solar stills: an experimental verification under local climate. Energy Convers Manag 50(9):2457-2461

46. Abdallah S, Badran $O O$ (2008) Sun tracking system for productivity enhancement of solar still. Desalination 220(1-3):669-676

47. Velmurugan V, Srithar K (2011) Performance analysis of solar stills based on various factors affecting the productivity-a review. Renew Sustain Energy Rev 15(2):1294-1304

48. Xiao G, Wang X, Ni M, Wang F, Zhu W, Luo Z, Cen K (2013) A review on solar stills for brine desalination. Appl Energy 103:642-652

49. Kwatra HS (1996) Performance of a solar still: predicted effect of enhanced evaporation area on yield and evaporation temperature. Sol Energy 56(3):261-266

50. Ward J (2003) A plastic solar water purifier with high output. Sol Energy 75(5):433-437

51. Naim, M. M., \& El Kawi, M. A. A. (2003). Non-conventional solar stills Part 1. Non-conventional solar stills with charcoal particles as absorber medium. Desalination, 153(1-3), 55-64

52. Naim, M. M., \& El Kawi, M. A. A. (2003). Non-conventional solar stills Part 2. Non-conventional solar stills with energy storage element. Desalination, 153(1-3), 71-80

53. Tabrizi FF, Dashtban M, Moghaddam H (2010) Experimental investigation of a weir-type cascade solar still with built-in latent heat thermal energy storage system. Desalination 260(1-3):248-253

54. Shalaby SM, El-Bialy E, El-Sebaii AA (2016) An experimental investigation of a v-corrugated absorber single-basin solar still using PCM. Desalination 398:247-255

55. Velmurugan V, Pandiarajan $S$, Guruparan $P$, Subramanian $L H_{\text {, }}$ Prabaharan CD, Srithar K (2009) Integrated performance of stepped and single basin solar stills with mini solar pond. Desalination 249(3):902-909

56. Panchal HN (2015) Enhancement of distillate output of double basin solar still with vacuum tubes. J King Saud Univ-Eng Sci 27(2):170-175

57. Nafey AS, Abdelkader M, Abdelmotalip A, Mabrouk AA (2001) Solar still productivity enhancement. Energy Convers Manag 42(11):1401-1408

58. Omara ZM, Kabeel AE (2014) The performance of different sand beds solar stills. Int J Green Energy 11(3):240-254

59. Arunkumar T, Kabeel AE, Raj K, Denkenberger D, Sathyamurthy R, Ragupathy P, Velraj R (2018) Productivity enhancement of solar still by using porous absorber with bubble-wrap insulation. J Clean Prod 195:1149-1161 
60. Nafey AS, Abdelkader M, Abdelmotalip A, Mabrouk AA (2002) Enhancement of solar still productivity using floating perforated black plate. Energy Convers Manag 43(7):937-946

61. Rashidi S, Rahbar N, Valipour MS, Esfahani JA (2018) Enhancement of solar still by reticular porous media: experimental investigation with exergy and economic analysis. Appl Therm Eng 130:1341-1348

62. Abdallah S, Abu-Khader MM, Badran O (2009) Effect of various absorbing materials on the thermal performance of solar stills. Desalination 242(1-3):128-137

63. Minasian AA, Al-Karaghouli AA (1995) An improved solar still: the wick-basin type. Energy Convers Manag 36(3):213-217

64. Sengar SH, Mohod AG, Kh YP, Modak SP, Gupta DK (2011) Design and development of wick type solar distillation system. Int J Sci Technol Educ Res 2(8):125-133

65. Murugavel KK, Srithar K (2011) Performance study on basin type double slope solar still with different wick materials and minimum mass of water. Renew Energy 36(2):612-620

66. Abdul-Wahab SA, Al-Hatmi YY (2013) Performance evaluation of an inverted absorber solar still integrated with a refrigeration cycle and an inverted absorber solar still. Energy Sustain Dev 17(6):642-648

67. Murugavel KK, Chockalingam KK, Srithar K (2008) An experimental study on single basin double slope simulation solar still with thin layer of water in the basin. Desalination 220(1-3):687-693

68. Omara ZM, Kabeel AE, Abdullah AS, Essa FA (2016) Experimental investigation of corrugated absorber solar still with wick and reflectors. Desalination 381:111-116

69. Omara ZM, Kabeel AE, Abdullah AS (2017) A review of solar still performance with reflectors. Renew Sustain Energy Rev 68:638-649

70. Tamini A (1987) Performance of a solar still with reflectors and black dye. Sol wind technol 4(4):443-446

71. Abdallah S, Badran O, Abu-Khader MM (2008) Performance evaluation of a modified design of a single slope solar still. Desalination 219(1-3):222-230

72. Estahbanati MK, Ahsan A, Feilizadeh M, Jafarpur K, Ashrafmansouri SS, Feilizadeh M (2016) Theoretical and experimental investigation on internal reflectors in a single-slope solar still. Appl Energy 165:537-547

73. Omara ZM, Kabeel AE, Younes MM (2013) Enhancing the stepped solar still performance using internal reflectors. Desalination 314:67-72

74. Tanaka H, Nakatake $Y$ (2007) Improvement of the tilted wick solar still by using a flat plate reflector. Desalination 216(1-3):139-146

75. Tanaka H, Nakatake Y (2009) One step azimuth tracking tiltedwick solar still with a vertical flat plate reflector. Desalination 235(1-3):1-8

76. Shanmugan S, Rajamohan P, Mutharasu D (2008) Performance study on an acrylic mirror boosted solar distillation unit utilizing seawater. Desalination 230(1-3):281-287

77. El-Samadony YAF, Abdullah AS, Omara ZM (2015) Experimental study of stepped solar still integrated with reflectors and external condenser. Exp Heat Transf 28(4):392-404

78. Khalifa AJN, Ibrahim HA (2011) Experimental study on the effect of internal and external reflectors on the performance of basin type solar stills at various seasons. Desalin Water Treat 27(1-3):313-318

79. Alaian WM, Elnegiry EA, Hamed AM (2016) Experimental investigation on the performance of solar still augmented with pinfinned wick. Desalination 379:10-15

80. Ayuthaya RPN, Namprakai P, Ampun W (2013) The thermal performance of an ethanol solar still with fin plate to increase productivity. Renew Energy 54:227-234
81. Srivastava PK, Agrawal SK (2013) Winter and summer performance of single sloped basin type solar still integrated with extended porous fins. Desalination 319:73-78

82. Tiris C, Tiris M, Erdalli Y, Sohmen M (1998) Experimental studies on a solar still coupled with a flat-plate collector and a single basin still. Energy Convers Manag 39(8):853-856

83. Rai SN, Tiwari GN (1983) Single basin solar still coupled with flat plate collector. Energy Convers Manag 23(3):145-149

84. Singh SK, Bhatnagar VP, Tiwari GN (1996) Design parameters for concentrator assisted solar distillation system. Energy Convers Manag 37(2):247-252

85. Abdel-Rehim ZS, Lasheen A (2007) Experimental and theoretical study of a solar desalination system located in Cairo. Egypt. Desalin 217(1-3):52-64

86. Shafii MB, Shahmohamadi M, Faegh M, Sadrhosseini H (2016) Examination of a novel solar still equipped with evacuated tube collectors and thermoelectric modules. Desalination 382:21-27

87. Kumar S, Dubey A, Tiwari GN (2014) A solar still augmented with an evacuated tube collector in forced mode. Desalination 347:15-24

88. Chong TL, Huang BJ, Wu PH, Kao YC (2014) Multiple-effect diffusion solar still coupled with a vacuum-tube collector and heat pipe. Desalination 347:66-76

89. Abad HKS, Ghiasi M, Mamouri SJ, Shafii MB (2013) A novel integrated solar desalination system with a pulsating heat pipe. Desalination 311:206-210

90. El-Sebaii AA, Ramadan MRI, Aboul-Enein S, Salem N (2008) Thermal performance of a single-basin solar still integrated with a shallow solar pond. Energy Convers Manag 49(10):2839-2848

91. Velmurugan V, Srithar K (2007) Solar stills integrated with a mini solar pond-analytical simulation and experimental validation. Desalination 216(1-3):232-241

92. Badran OO, Al-Tahaineh HA (2005) The effect of coupling a flat-plate collector on the solar still productivity. Desalination 183(1-3):137-142

93. Ahmed ST (1988) Study of single-effect solar still with an internal condenser. Sol wind technol 5(6):637-643

94. Sahota L, Tiwari GN (2016) Effect of Al2O3 nanoparticles on the performance of passive double slope solar still. Sol Energy 130:260-272

95. Arunkumar T, Jayaprakash R, Denkenberger D, Ahsan A, Okundamiya MS, Tanaka H, Aybar HŞ (2012) An experimental study on a hemispherical solar still. Desalination 286:342-348

96. Sakthivel M, Shanmugasundaram S (2008) Effect of energy storage medium (black granite gravel) on the performance of a solar still. Int J Energy Res 32(1):68-82

97. Panchal HN, Shah PK (2012) Effect of varying glass cover thickness on performance of solar still: in a winter climate conditions. Int J Renew Energy Res (IJRER) 1(4):212-223

98. Akash BA, Mohsen MS, Osta O, Elayan Y (1998) Experimental evaluation of a single-basin solar still using different absorbing materials. Renew Energy 14(1-4):307-310

99. Eldalil KM (2010) Improving the performance of solar still using vibratory harmonic effect. Desalination 251(1-3):3-11

100. Bassam A, Abu-Hijleh K, Rababa'h HM (2003) Experimental study of a solar still with sponge cubes in basin. Energy Convers Manag 44(9):1411-1418

101. El-Sebaii AA, Ramadan MRI, Aboul-Enein S, El-Naggar M (2015) Effect of fin configuration parameters on single basin solar still performance. Desalination 365:15-24

102. Badran $O O$ (2007) Experimental study of the enhancement parameters on a single slope solar still productivity. Desalination 209(1-3):136-143 
103. Fathy M, Hassan $H$, Ahmed MS (2018) Experimental study on the effect of coupling parabolic trough collector with double slope solar still on its performance. Sol Energy 163:54-61

104. Al-harahsheh M, Abu-Arabi M, Mousa H, Alzghoul Z (2018) Solar desalination using solar still enhanced by external solar collector and PCM. Appl Therm Eng 128:1030-1040

105. Kabeel $A E$, Abdelgaied $M$, Eisa $A$ (2018) Enhancing the performance of single basin solar still using high thermal conductivity sensible storage materials. J Clean Prod 183:20-25

106. Sriram V, Kondraganti V, Lokireddy CTR, Jeevahan J, Joseph GB, Durai Raj RB, Mageshwaran G (2019) Investigation of effect of the Fresnel lens on the performance of the double slope single basin solar still. Int J Ambient Energy. https://doi. org/10.1080/01430750.2018.1563810
107. Elbar ARA, Hassan H (2019) Experimental investigation on the impact of thermal energy storage on the solar still performance coupled with PV module via new integration. Sol Energy 184:584-593

108. Chaichan MT, Kazem HA (2018) Single slope solar distillator productivity improvement using phase change material and Al2O3 nanoparticle. Sol Energy 164:370-381

Publisher's Note Springer Nature remains neutral with regard to jurisdictional claims in published maps and institutional affiliations. 